\title{
The Implementation Strategy of Non-Cash Payment Systems in The Islamic Boarding School Through Analytical Hierarchy Process Approach
}

\author{
Ahmad Ghifary Rizalun Nafis \\ Universitas Diponegoro, Semarang, Indonesia \\ email: nafisghifary@gmail.com \\ Nurfatin Nazilah Binti Zainol \\ Islamic Science University of Malaysia, Malaysia \\ email: nurfatinnazilah@gmail.com \\ Millaturrofi'ah \\ Universitas Islam Negeri Walisongo Semarang, Indonesia \\ email: millaforshei@gmail.com
}

\begin{abstract}
This study aimed to observe the problems of non-cash payments implementation in Islamic boarding schools. This research uses descriptive qualitative-quantitative by using the analytical hierarchy process development model (AHP). The results indicated the three most dominant problems, including resources, communication, and governance systems. The literature review and interview results could detail the three main aspects, then examined using AHP. The results showed that these three aspects have priority values with a percentage of the resource aspect is $40 \%, 38 \%$ for the communication aspect, and $22 \%$ for the governance system aspect. This study uses primary data through interviews (in-depth interviews) with the experts and practitioners who understand the issues discussed, followed by filling out questionnaires to respondents at the second meeting. This study discusses the analysis of the problem and the main factors in the implementation of non-cash payments in Islamic boarding schools. No previous studies have made Islamic boarding schools the object of research. This research contributes to stakeholders in making policies if they will implement non-cash payments in Islamic boarding schools.
\end{abstract}

Keywords: Implementation; Non-cash payment; Islamic Boarding School; Analytical Hierarchy Process

Abstrak: Penelitian ini bertujuan untuk mengalisis masalah dan faktor utama yang menghambat jika akan diimplementasikan di pondok pesantren. Penelitian ini menggunakan deskritif kualitatif-kuantitatif dengan menggunakan model pengembangan analytical hierarchy process (AHP). Hasilnya menyimpulkan bahwa terdapat tiga masalah utama pada yang paling

Economica: Jurnal Ekonomi Islam - Volume 12, Nomor 1 (2021) 
dominan yaitu masalah sumber daya, komunikasi dan sistem tata kelola. Kajian literatur dan hasil wawancara dapat merinci tiga aspek utama tersebut yang kemudian diteliti menggunakan AHP. Hasil mengemukakan bahwa ketiga aspek tersebut memiliki nilai prioritas dengan presentase aspek sumber daya sebesar $40 \%$, aspek komunikasi sebesar 38\% dan aspek sistem tata kelola sebesar $22 \%$. Data primer melalui wawancara (indepth interview) dengan pakar dan praktisi, yang memiliki pemahaman tentang permasalahan yang dibahas yang dilanjutkan dengan pengisian kuesioner pada responden di pertemuan kedua. Penelitian ini membahas tentang analisis masalah dan faktor utama dalam pelaksanaan pembayaran nontunai di pondok pesantren. Belum ada penelitian sebelumnya yang menjadikan pesantren sebagai objek penelitian. Penelitian ini memberikan kontribusi kepada para stakeholder dalam membuat kebijakan jika menerapkan pembayaran nontunai di pondok pesantren.

Kata Kunci: Implementasi; Pembayaran Non Tunai; Pondok Pesantren; AHP 
The Implementation Strategy of Non-Cash Payment ...

\section{Introduction}

Indonesia is entering a decade of a digital revolution in all fields, including in the economic field. The technology cycle that is getting shorter becomes a challenge for regulators to create variety, innovation, and complexity in the payment system. Therefore, Bank Indonesia, as The declaration of the GNNT, is a refreshment of Government Regulation No. 82 of 2012 concerning the Implementation of Electronic Systems and Transactions. The National NonCash Movement aims to increase public awareness of the use of non-cash instruments. It will form a community or society using more non-cash transactions or is also known as the Less-Cash Society (LCS) for their economic activities (Sutarmin and Susanto 2017).

The number of non-cash transactions in Indonesia shows a positive movement every year. However, compared to other ASEAN countries, electronic-based payment transactions in Indonesia are still relatively low. Indonesia ranks the bottom 4 (Kusnandar 2019c), so that Bank Indonesia, together with bankings as the main players in providing payment system services to the public, needs to have the same vision and strong commitment to encourage the use of non-cash transactions in realizing the Less Cash Society ( LCS).

Until October 2019, the number of Indonesia's adult population whom financial services had not served reached 92 million, becoming the most in Southeast Asia (Kusnandar 2019b). On the other hand, Indonesia has the largest Muslim population in the world. Based on data from Global religious futures, the total Muslim population of Indonesia in 2020 reached 229,6 million, or the equivalent of $87.2 \%$ of the population. Furthermore, Indonesian Muslims are predicted to increase to 263.92 million in 2050 (Kusnandar 2019a). This largest Muslim demographic condition has excellent potential to develop inclusive finance and accelerate access to non-cash transactions to be comprehensive, especially since Muslims in Indonesia have a unique education system, namely Islamic boarding schools.

Economica: Jurnal Ekonomi Islam - Volume 12, Nomor 1 (2021) 
Islamic boarding schools are the treasures of unique Islamic education in Indonesia. They have special characteristics that are not fully owned by public schools, such as kiai, santri, pondok, Kitab kuning, and a culture different from formal educational institutions in general. Over the centuries, Islamic boarding schools have played an essential role in social dynamics at the local and national levels. It is a vehicle for Islamic education and a means of accelerating change and mobility for the nation (Ryandono 2018). However, so far, studies on pesantren have only looked at pesantren from the dimensions of social and political education. Not many see the pesantren from the economic side it has (Nadzir 2015).

Data from the Indonesian Ministry of Religion records that 28,519 Islamic boarding schools are spread throughout Indonesia, with 4,354,309 students (Kemenag 2020). Therefore, Islamic boarding schools can be a distribution channel in providing access to finance for most people who embrace Islam.

For the success of GNNT activities, Bank Indonesia took the initiative to develop a non-cash payment ecosystem in Islamic boarding schools. This noncash payment system is hoped to open complete access to financial services for the public, especially in the Islamic Boarding School environment, which will eventually lead to the formal financial sector (Bank Indonesia 2019). Furthermore, the community approach through the Islamic boarding school is considered appropriate because the Islamic boarding school has an environment, a strong network, and a significant influence on the alumni and the surrounding community. Thus, it can make pesantren be a tremendous potential institution to act as GNNT agents in its environment.

One of the Islamic boarding schools in Indonesia which has thousands of students (santri) and focuses on developing the community's economy is the Islamic Boarding School of Tahfidzul Qur'an Al Asy'ariyyah, Kalibeber, Wonosobo. The caregiver policy regarding being allowed to transact outside the boarding school is stated in the qonun or rules of the Al-Asy'ariyyah Islamic boarding school article 1, paragraph $91425 \mathrm{H}$ or $2004 \mathrm{AD}$, which says: "It is 
permissible to carry out economic activities such as eating and buying goods outside the boarding school before maghrib time." With this regulation, it can affect purchasing power so that the societies" income increases. In the practice of transactions in the Islamic boarding school environment, there are still many ordinary people using non-cash payments (Saadah 2012). So that if all boarding school students have non-cash payment facilities, the community will indirectly participate using non-cash payments.

Bank Indonesia has conducted trials at several Islamic boarding schools such as the Daarut Tauhid Islamic Boarding School, Bandung West Java, the Tebuireng Jombang Islamic Boarding School, the Al Mawaddah Islamic Boarding School in East Java, as well as the Nurul Jadid Porbolinggo Islamic Boarding School, East Java. However, even though many Islamic boarding schools have been tested using a non-cash payment system, the implementation of non-cash payments among Islamic boarding schools has not shown a perfection and a significant development (Fatimah and Suib 2019). In its practice, the implementation of digital financial services in Islamic boarding schools is a little more complicated than in general, such as in the AlAsy'ariyyah Islamic boarding school.

Islamic boarding schools have regulations that require students not to carry electronic goods and limit the students to have activities outside the boarding school. In addition, students (santri) have limitations in accessing non-cash payments that require electronic access, such as smartphones or ATM services. Apart from limited electronic access, banks' operational costs are also considered burdensome for actors such as students, parents, and the Islamic boarding school itself. Furthermore, the complete human resources and stereotypes developing in some Islamic boarding schools regarding the rule (Syariah) of using banking services are also considered problems that must be resolved (Fatimah and Suib 2019).

Some of the obstacles in implementing the payment system in the Islamic boarding schools described above have hampered the growth of non-cash 
transactions in the Islamic boarding school environment that involve the wider community. Furthermore, according to Nurul and Ningrat (2019); Ramadhan and Solekah (2020), non-cash payments, especially in Islamic boarding schools, have three critical obstacles, namely aspects of human resources (HR), aspects of communication, and aspects of governance systems. This is also confirmed by the research of Hendrawan, Anisah, and Nafidah (2019); Dona and Khaidir (2018) regarding the implementation of non-cash payments at an institution, where the main problems are system problems, application errors, Human Resources (HR), and the institutional leaders' perspective. Thus, several factors hindering Islamic boarding schools have not been optimal for conducting non-cash payment transactions, making it necessary to research further the obstacles to the implementation of noncash payments among them.

Many previous researchers have researched the implementation of noncash payments. Still, there has been no more specific research on the pesantren community, considering that pesantren is a central place for Islamic education and the center of surrounding economic activities. Therefore, the updating of this research reveals how and what are the main obstacles in implementing non-cash payments. Furthermore, research is also needed to establish a competitive strategy based on a broad perspective and problem analysis in the field. Furthermore, this study's final objective is to find an effective strategy model for implementing digital financial services from the existing problem in Islamic boarding schools based on the Analytical Hierarchy Process (AHP).

Analytical Hierarchy Process (AHP) is a mathematical theory that can analyze the effect by using an assumption approach to solve the form of the problem. This method is to solve problems with various considerations on the complexity of the problem by describing the synthesis along with the priority scale from no priority to the largest one. AHP can also solve the dependence 
factor model systematically. The AHP method makes decisions by considering and validating practical experiences (Saaty 2004).

\section{Literature review}

\section{The implementation of non-cash payment}

The implementation theory can refer to the view of Grindle (2017), where implementation is a process of administrative action at a particular program level, and the process of implementation will be carried out if goals and objectives have been set to achieve a goal. In line with the thoughts of Van Meter and Van Horn cited by Parsons (1995), who are the first era researchers on policy implementation studies, define implementation by actions taken by the government and private organizations both in groups to achieve a goal.

According to Edward III (1989), four main factors influence the implementation of an activity, namely communication, resources, bureaucracy, and the implementer's attitude. The clear and consistent transmission communication supported by human resources, budget, and good facilities and bureaucracy will undoubtedly implement an activity run well.

Several previous authors have conducted research related to the implementation of non-cash payments. For example, the research of Ramadhan (2018), examined the constraints and solutions for implementing non-cash payments at Selecta Recreation Park, Batu City, East Java. His research revealed the main objectives and problems in implementing noncash payments. The objectives of the implementation are to be safe, efficient, accountable, and transparent. In addition, the problems encountered are related to signal difficulties, human resource problems, systems that have not been integrated, and low user loyalty.

Fatimah and Suib (2019) explain the payment system transformation in the Nurul Jadid Islamic Boarding School through e-money. The 
implementation of non-cash payments at the Islamic Boarding School aims to improve its quality services and cashless society. Furthermore, creating a paperless office environment where the non-cash payment system in Islamic Boarding School will make it easier to supervise students' (santris') finances, making transactions easier, faster, and more practical. However, in practice, using the non-cash payment system in Islamic boarding schools has three significant obstacles, namely aspects of human resources (HR), communication, and system. This is also reinforced by Hendrawan, Anisah, and Nafidah's (2019) research regarding the implementation of non-cash payments. The main problems are system problems, Human Resources (HR), and the institutional leaders' perspective.

Marwini and Salam's (2020) research also explains that non-cash payments at Islamic boarding schools are a form of progress made in Indonesian cultural education institutions and can be a place for the growth of the sharia economic system in a broad sense. However, Islamic boarding schools need to be given direction regarding trust in third parties and training for human resources to realize the benefits and apply for cashless payments properly in the Islamic boarding school environment.

Kresnawati, Wahib, and Pertiwi (2018), in their research on the use of non-cash payments by students, showed enthusiasm and no resistance by students. However, there are obstacles to the non-cash payment system in Islamic boarding schools. The government has not created a unique system with the Islamic boarding school culture, and the pesantren financial management cannot use non-cash payment transactions (Marwini and Salam 2020).

There have not been many studies explaining the non-cash payment strategies at Islamic boarding schools through AHP. Still, Sutarmin and Susanto (2017) describe supporting strategies for implementing UMKM noncash payments. Their research emphasizes more on how to communicate and the transaction tool system that will support the implementation. The 
research of Hendrawan, Anisah, and Nafidah (2019) also examined non-cash payments in the governance of government institutions. Their research revealed the less intense communication, limited human resources, and an inadequate system so that the implementation of non-cash payments was less optimal.

Based on previous research, the core problem of implementing non-cash payments in Islamic boarding schools can be reduced to 3 critical things: resources, communication, the implanter's attitude, and the management system.

Previous studies use various methods to process data, including MANOVA, factor analysis, and descriptive statistical analysis such as ANOVA, t-test, and cross-tabulation analysis. This research will use the analytical hierarchy process (AHP) method to determine the priority strategies that can be used to implement non-cash payments in Islamic boarding schools, especially at the Al Asy'ariyyah Islamic boarding school, Kalibeber, Wonosobo.

\section{Islamic boarding school of Tahfidzul Qur'an Al Asy'ariyyah, Kalibeber}

Al-Asy'ariyyah Kalibeber Islamic boarding school is located in Kalibeber Village, Mojotengah District, Wonosobo Regency. Pondok Pesantren AlAsy'ariyyah Kalibeber is one of the Islamic educational institutions that prints its students so that they have the soul and ethics by the Qur'an. In particular, this Islamic boarding school educates and fosters a generation of Muslims who can be used as role models by the general public. Al-Asy'ariyyah Islamic boarding school Kalibeber has a long history. Starting from Kyai Muntaha bin Nida Muhammad (1832-1859), continued by KH. Abdurrochim (1860-1916), then continued by KH. Asy'ari (1917-1949), to KH. Muntaha Al-Hafidz (1950) (Saadah 2012).

Every year the number of students at the Al-Asy'ariyyah Islamic boarding school in Kalibeber has increased significantly. The average santri of this

Economica: Jurnal Ekonomi Islam - Volume 12, Nomor 1 (2021) 
boarding school comes from the community around Wonosobo, but there are also students from outside Central Java or Java. The Al-Asy'ariyyah Kalibeber Islamic boarding school students are not required to live in dormitories, so some live in their own homes.

At first, the Al-Asy'ariyyah Islamic boarding school was a simple Islamic boarding school with only a few students, but since the leadership of KH. Muntaha Al-Hafidz in 1950, innovation and development began to be carried out. He maintains an education system that studies the Qur'an and the study of the yellow book. In 1962, KH. Muntaha Al-Hafidz began to implement and develop the concept of modernization of Islamic boarding school education by establishing a formal school that combines the Diknas system and the Ketakhassusan system (Saadah 2012).

\section{Analytical Hierarchy Process}

Analytical Hierarchy Process (AHP) is a mathematical theory that can analyze the effect by using an assumption approach to solve the form of the problem. This method solves problems with various considerations on the problem complexity by describing the synthesis and the priority scale from no priority to the greatest one. AHP can also solve the dependent factor model systematically. The AHP method makes decisions by considering and validating practical experiences (Saaty 2004).

AHP includes personal considerations and values logically based on imagination, experience, and knowledge in the process. On the other hand, AHP provides a framework for group participation in decision-making or problem-solving. 
Table 1. Scale of relative importance

\begin{tabular}{lc}
\hline Definition & Intensity of Importance \\
\hline Equal Importance & 1 \\
Weak & 2 \\
Moderate importance & 3 \\
Moderate plus & 4 \\
Strong importance & 5 \\
Strong Plus & 6 \\
Very strong or demonstrated & 7 \\
importance & 8 \\
Very, very strong & 9 \\
\hline
\end{tabular}

Source: (Saaty 2004)

AHP has four hypotheses to be used as a theoretical basis as table 1 (Saaty 2004). Reciprocally, this hypothesis states that if PC (EA, EB) is the pairs' comparative value of elements $A$ and $B$, for example, if $A$ is five times greater than $B$, then $B$ is $1 / 5$ of the size of $A ; 2$ ). Homogeneity means that the elements compared in the AHP framework structure should not have a huge difference, leading to more significant errors in determining the assessment of supporting elements that affect decisions; 3). Priority, namely absolute weighting using an interval scale [0.1] and as a measure of relative dominance; 4). The dependence condition assumes that the arrangement can be composed of the components that form a cluster.

\section{Methods}

This study used primary data through interviews (in-depth interviews) with the experts and practitioners, who understand the issues discussed, followed by filling out questionnaires to respondents at the second meeting. This research was included in the category of qualitative-quantitative analysis, which aimed to capture a value view represented by experts and actors regarding the implementation of non-cash payments in Islamic boarding schools. 
Respondents in this study were selected to consider the respondent's understanding of the problem of non-cash payment services in Islamic boarding schools. The number of respondents in this study consisted of 4 experts and practitioners who are competent and directly involved in the field. Requirements for the valid respondents in AHP are those who master or are experts in their fields. Therefore, the author chose respondents from caregivers or boarding school administrators who understand the finances and conditions of the students. While respondents from academics who better understand economic and pesantren issues, and respondents from officers or practitioners of LKD implementation from Indonesian banks and banks who focus on implementing GNNT.

\section{The research stages}

Setting priorities in AHP, Saaty (2006) is determined by arranging elements in a problem using or making pairwise comparisons, where each element is compared in pairs against a specified criterion. The pairwise comparison matrix form is as table 2 :

Filling in the pairwise comparison matrix uses numbers that describe the relative importance of one element over another. For example, the scale defines and describes the values 1-9 that are set as a consideration in comparing pairs of similar elements at each level of the hierarchy against a criterion that is one level above it.

Table 2. A table of the pairwise comparison matrix

\begin{tabular}{ccccc}
\hline C & A1 & A2 & A3 & A4 \\
\hline A1 & 1 & & & \\
A2 & & 1 & 1 & \\
A3 & & & & 1 \\
A4 & & & & \\
\hline
\end{tabular}

It explains that $\mathrm{C}=$ criteria and $\mathrm{A}=$ Alternative

Source: (Saaty 2006) 
In this study, the pairwise appeal scale in the preparation of AHP is needed to determine the alternative priority arrangements of problem criteria and strategies for implementing non-cash payments in Islamic boarding schools.

After all, considerations are numerically translated; their validity needs to be re-evaluated using a consistency test. Consistency in the decision-making of the key person in determining the priority of elements on the criteria is necessary to obtain valid results in the real world. AHP measures the overall consistency of various considerations through the consistency ratio. The consistency ratio value should be 10 percent or less $(\mathrm{CR}<0.1)$. If it is more than $10 \%$, it needs to be fixed. The consistency ratio measurement (CR) is as follows:

$$
C R=\frac{C I}{R I}
$$

Meaning that:

CR: Consistency Ratio

CI: Consistency Index

RI: Random Index

AHP data processing can use from one expert respondent. However, in its application, the criteria and alternatives assessment are carried out by several multidisciplinary experts. So that the opinion of several experts needs to be checked one by one to know the consistency, while the consistent opinion is then combined using the geometric average calculation (Saaty 2004). The combined research results are then processed by the AHP procedure using the Microsoft Excel 2007 application. The stage of the AHP method is as figure 1: 
Figure 1. The stage of analytical hierarchy process

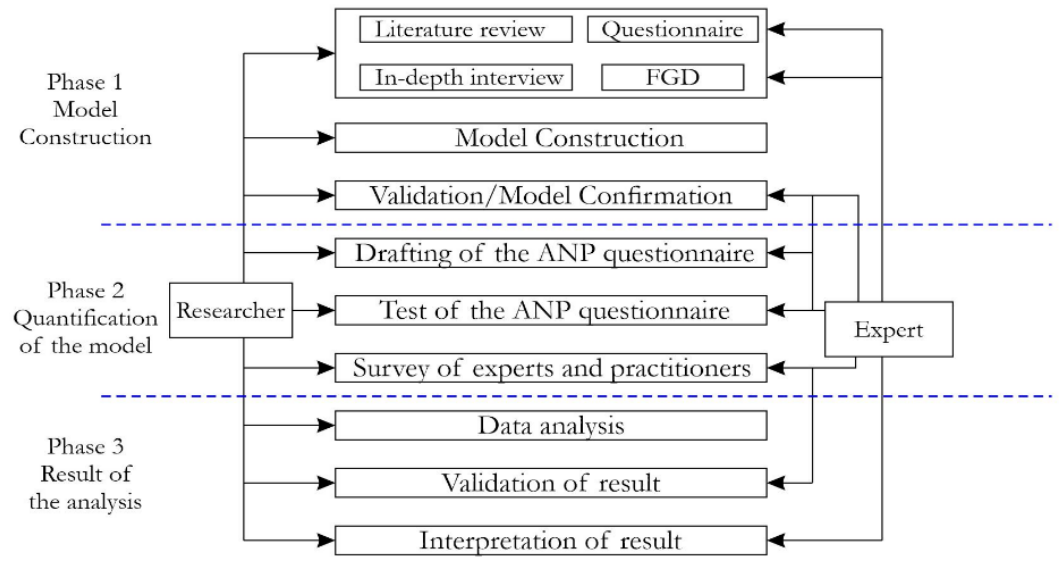

Source: (Ascarya 2015)

\section{Result and discussion}

\section{Problem identification}

Islamic boarding schools have an excellent opportunity to implement the concept of non-cash payments. Still, in the process, the Islamic boarding schools also have various obstacles that must be resolved. It also includes the Tahfidz Al Asy'ariyyah Islamic boarding school, Kalibeber, Wonosobo. Based on interviews with managers, there are 14 Islamic boarding schools in Kalibeber with approximately 5,400 students. This certainly has the potential to become a non-cash payment agent and increase financial inclusion in the regions.

This study studies the constraints and priority strategies for implementing cashless payments in Islamic boarding schools. The criteria for implementation problems in this study are based on the literature review and research by Fatimah and Suib (2019); Hendrawan, Anisah, and Nafidah 
(2019); Kresnawati, Wahib, and Pertiwi (2018); Sutarmin and Susanto (2017); Baharun and Ardillah (2019); and Ramadhan (2018).

Based on literature review and previous research, three criteria are identified as priority problems in implementing non-cash payments in Islamic boarding schools. These are then taken into consideration to be arranged hierarchically to be processed to be the criteria for a strategic decision. The three criteria are aspects of resources, communication, and governance systems. The criteria in the research model mentioned were expanded in consultation with experts and practitioners on Islamic boarding schools and non-cash payments.

The experts parsed the resources sub-criteria. One of the reasons is the lack of quality and work ethic by the Islamic boarding school's financial managers. Discipline and code of ethics for people who work in the financial sector are not wholly-owned in the learning method of the Islamic boarding schools. Apart from that, capital considerations are also an obstacle in its implementation. Capital and investment in Islamic boarding schools allocated for the non-cash payment system have never been given space to be budgeted. Infrastructure implementation has not been resolved, such as poor signals, the few automated teller machines, and cooperatives that serve non-cash payments have also not been accommodated. The confusing information and authority between service providers, managers, and beneficiaries also become a resource problem.

The interview result also found information about the financial managers' lack of insight and the parents and the surrounding community regarding the non-cash payment system, which is minimal. Therefore, in its implementation, some things need to be corrected. More than that, basic things such as individual interest in implementing the non-cash payment system are also considered low, based on onboarding school policymakers' views that the non-cash payment system will add complexity and hassle to the application process.

Economica: Jurnal Ekonomi Islam - Volume 12, Nomor 1 (2021) https://journal.walisongo.ac.id/index.php/economica 
Communication problems finally appeared and must be parsed immediately to find a solution. In addition, another problem in Islamic boarding schools is the policymakers' views, who think that the non-cash payment system is not a priority and is considered less applicable and unnecessary. This is also reinforced by parents who do not trust the non-cash payment system, preferring and are comfortable using existing and everyday transactions. In addition, the perception that is still developing in the Islamic boarding school environment considers non-cash payment services still in doubt and debatable about the Islamic law in using these services.

According to the experts and practitioners, the implementation of noncash payments has no application system by the Islamic boarding school's culture. As a result, many students are still prohibited from using electronic devices and are in areas where signal facilities are insufficient. In addition, bad applications will impact user loyalty and trust in operating non-cash payment systems (Kresnawati, Wahib, and Pertiwi 2018).

Based on the interviews with several experts, literature studies, and problem descriptions above, there are several strategic descriptions of the above problems. These strategies include:

The first, Strategies on the human resources aspect, This strategy consists of several steps, namely: (1)Providing training and education for human resources both in quality and quantity, (2)Adequacy of capital and investment to ensure the implementation of the program, (3)The fulfillment of proper facilities and infrastructure, (4)The memorandum of understanding and the authority to implement policies are implemented on a mutually beneficial basis. Unfortunately, the human resources of the Foundation are a problem. This was triggered by debates regarding transactions that were not allowed by Islam, such as Riba, Gharar, and Maysir.

The second, Strategies on the communication aspect, This strategy consists of several steps, namely: (1)Performing interactive communication 
regarding the objectives and targets of implementing cashless payments clearly and consistently, (2)Introduction of non-cash payment methods to parents and local communities, (3)Supervision and support from the central bank, (4)Guarantee of halal transactions in the management system.

The third, Strategies on the governance system aspect, This strategy consists of several steps, namely: (1)Provision of an integrated, compatible, and up to date application system, (2)A better improvement of signal providers in Islamic boarding schools, (3)Provision of special techniques to deal with human or system error incidents, (4)Providing applications that are by the Islamic boarding school culture.

\section{The AHP network}

Based on the problem identification, the strategy for implementing noncash payments at Islamic boarding schools as stated above forms the AHP structure network as figure 2 :

Figure 2. Hierarchical structure

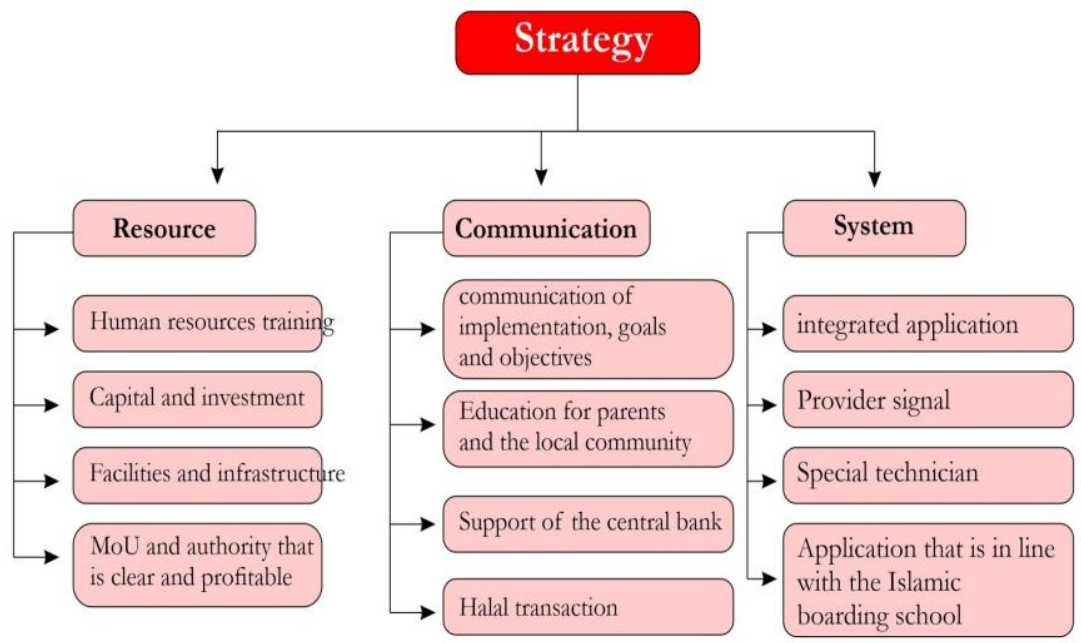

Source: the processed research data

Economica: Jurnal Ekonomi Islam - Volume 12, Nomor 1 (2021)

https://journal.walisongo.ac.id/index.php/economica 
Ahmad Ghifary Rizalun Nafis, Nurfatin Nazilah Binti Zainol, and Millaturrofi'ah

\section{The consistency test}

The consistency test is carried out by arranging the relative importance of each criterion or alternative, which is expressed as normalized relative weight. The determination of whether the tested comparison matrix is consistent or not can be seen from the magnitude of the ratio between $\mathrm{CI}$ and RI. If the ratio value is less than 0.1 , it can be concluded that the tested comparison matrix is consistent (Firdaus, Harmini, and Farid 2011).

This study uses multidisciplinary respondents, so it is necessary to check the consistency of the answers one by one before all the results of the respondents' answers are combined into one by calculating the geometric mean (Saaty 2004). The consistency value of each respondent can be seen as table 3 .

Table 3 shows the CR value for each respondent in each cluster. The subcluster in this study has a CR value $<0.1$, so the pairwise calculation for each criterion and sub-criterion can be concluded to be consistent.

Table 3. The consistency ration value of each respondent

\begin{tabular}{lcccc}
\hline \multicolumn{1}{c}{ Respondent } & Strategy & $\begin{array}{c}\text { Human } \\
\text { Resources } \\
\text { Strategy }\end{array}$ & $\begin{array}{c}\text { Trust } \\
\text { Strategy }\end{array}$ & $\begin{array}{c}\text { System } \\
\text { Strategy }\end{array}$ \\
\hline Academics & 0.01 & 0.0889 & 0.0194 & 0.0086 \\
Islamic boarding school's caregiver & 0.019 & 0.0086 & 0.0163 & 0.0241 \\
digital financial services manager & 0.002 & 0.0086 & 0.0133 & 0.0194 \\
Bank Indonesia & 0.06 & 0.0448 & 0.0374 & 0.0220 \\
CR after being merged & $\mathbf{0 . 0 0 9}$ & $\mathbf{0 . 0 1 0 9}$ & $\mathbf{0 . 0 0 5 0}$ & $\mathbf{0 . 0 0 6 1}$ \\
using geometric mean & & & & \\
\hline
\end{tabular}

Source: The processed research data 


\section{The result of the analysis}

After carrying out the calculation steps of the AHP method described above and processed using the help of the Microsoft Excel 2017 application, a table for calculating the final weight of each cluster and sub-cluster is obtained and becomes the result of the study. The results of the calculation of the final weight showing the priority of the three clusters and sub-clusters can be seen in the following table 4 :

Table 4. The weighting of strategy clusters and sub clusters

\begin{tabular}{|c|c|c|c|c|}
\hline \multicolumn{2}{|c|}{ Cluster } & \multicolumn{3}{|l|}{ Sub-Cluster } \\
\hline Criteria & Value & Sub Cluster & $\begin{array}{l}\text { Value of each } \\
\text { criterion }\end{array}$ & Value \\
\hline \multirow[t]{4}{*}{ Resource } & 0.40 & $\begin{array}{l}\text { Providing training and education for } \\
\text { human resources both in quality and } \\
\text { quantity }\end{array}$ & 0.19 & 0.08 \\
\hline & & $\begin{array}{l}\text { Adequate capital and investment to } \\
\text { ensure the implementation of the } \\
\text { program. }\end{array}$ & 0.26 & 0.11 \\
\hline & & $\begin{array}{l}\text { The fulfillment of proper facilities and } \\
\text { infrastructure }\end{array}$ & 0.24 & 0.10 \\
\hline & & $\begin{array}{l}\text { Information and authority for policy } \\
\text { implementation are implemented clearly } \\
\text { and guaranteed. }\end{array}$ & 0.30 & 0.12 \\
\hline \multirow[t]{4}{*}{$\begin{array}{l}\text { Communi } \\
\text { cation }\end{array}$} & 0.37 & $\begin{array}{l}\text { Performing interactive communication } \\
\text { regarding the goals and objectives of } \\
\text { implementing cashless payments clearly } \\
\text { and consistently }\end{array}$ & 0.29 & 0.11 \\
\hline & & $\begin{array}{l}\text { Introduction of non-cash payment } \\
\text { methods to parents and local } \\
\text { communities }\end{array}$ & 0.20 & 0.07 \\
\hline & & $\begin{array}{l}\text { Supervision and support from the } \\
\text { central bank }\end{array}$ & 0.29 & 0.10 \\
\hline & & $\begin{array}{l}\text { Guarantee of halal transactions in the } \\
\text { management system. }\end{array}$ & 0.24 & 0.09 \\
\hline \multirow[t]{4}{*}{$\begin{array}{l}\text { Governan } \\
\text { ce System }\end{array}$} & 0.22 & $\begin{array}{l}\text { Provision of an integrated, compatible, } \\
\text { and up-to-date application system. }\end{array}$ & 0.40 & 0.09 \\
\hline & & $\begin{array}{l}\text { Improvement of signal providers to } \\
\text { make it better in the Islamic boarding } \\
\text { school area. }\end{array}$ & 0.12 & 0.03 \\
\hline & & $\begin{array}{l}\text { Provision of special techniques to deal } \\
\text { with human or system error incidents. }\end{array}$ & 0.14 & 0.03 \\
\hline & & $\begin{array}{l}\text { Provision of applications that is in line } \\
\text { with the Islamic boarding school culture }\end{array}$ & 0.34 & 0.08 \\
\hline Total & 1,00 & Total & 3,00 & $\mathbf{1 , 0 0}$ \\
\hline
\end{tabular}

Source: the processed research data

Economica: Jurnal Ekonomi Islam - Volume 12, Nomor 1 (2021) 
Based on the data at table 4, which is the consensus of experts and practitioners, it is revealed that the strategic cluster that is the priority in implementing non-cash payments is the resource aspect that reaches $40 \%$, then the communication aspect which shows $38 \%$ and finally the governance system aspect at $22 \%$.

The discussion on the priority order of strategies in each aspect is as follows: The first, Human Resources Aspect. The value of the resource strategy is that the information and the authority to implement policies are implemented clearly and guaranteed, amounting to 0.3047 or $30 \%$. This is in line with the priority problem on resources, where individual interest from the Islamic boarding school officers and parents in implementing non-cash payments is a significant problem. The next priority regarding the strategy on resources is adequate capital and investment to ensure the implementation of the program, fulfillment of proper facilities and infrastructure.

According to the expert, the second, Communication Aspect, the communication aspect has $38 \%$ of the three aspects considered important in implementing non-cash payments in Islamic boarding schools. The largest sub-cluster on communication is conducting interactive communication regarding the objectives and targets of implementing cashless payments clearly and consistently. Experts assume that if communication is carried out interactively, bringing together goals, objectives, and future opportunities for all parties involved, there will be a midpoint in the success of these non-cash payment implementation activities and programs. The following communication cluster is supervision and support from the central bank, guarantees halal transactions in its management system, and finally, introduces non-cash payment methods to parents and the surrounding community.

The third, System Aspect, The strategic factor, has the lowest value of $22 \%$. The strategic factor in the system with the highest value is providing an integrated, compatible, and up-to-date application system, which is $40 \%$. 
Furthermore, in the strategic aspect of the governance system, application provider factors are adjusted to the culture and condition of the Islamic boarding school, namely 0.3391 or $34 \%$. Provision of special techniques to overcome the incidence of human and system error reach $14 \%$. Finally, fixing the signal provider to make it better in the boarding school area is $11 \%$.

The sub-criteria for this overall strategy will find the priority of the cumulative strategy if it is calculated by the cumulative percentage based on the percentage of each criterion. The top 5 strategies obtained are as follows:

\section{Information and authority of the implementation policy are implemented clearly and guaranteed}

Experts and practitioners consider this strategy to be the top priority strategy for implementing non-cash payments in Islamic boarding schools with a cumulative value of $12 \%$, which is, of course, departing from the descriptions of the problems above. In the early stages of implementation, clear and consistent information and jointly regulated authority so that a good agreement occurs without being harmed is a critical initial stage and must be implemented.

Islamic boarding schools with a large mass base have concerns if the noncash payments practice harms the officers, students, and parents, such as high administrative costs, complicated registration processes, and the improper misuse of personal data. Those are the description showing the response of Islamic boarding schools related to implementing a non-cash payment system that is explained explicitly by the caregiver of the Al Asy'ariyyah Islamic boarding school Kalibeber, Wonosobo.

However, suppose the banking sector, central bank, and pesantren are given space to communicate and carry out mutually beneficial memorandums of understanding. In that case, the potential for pesantren to be heard and considered is much greater. 


\section{They are performing interactive communication regarding the objectives and targets of implementing cashless payments clearly and consistently}

In addition to information and authority policies which is being priority considerations, conducting interactive communication regarding the needs of banks and central banks, the needs and culture of Islamic boarding schools is the second strategy with a value of $11 \%$. In the interview, Bank Indonesia stated that coordinating activities with all parties is the priority activity. This coordination activity provides education about the opportunities and role of Islamic boarding schools for GNNT as a full driver of the use of non-cash payments. Furthermore, the limitations on the GNNT implementation target allowed by the Islamic boarding school, the registration procedures, and procedures determined by the service provider are complex discussions where interactive, open, and transparent communication is the best solution.

\section{The adequacy of capital and investment to ensure the implementation of the program}

The following strategy provides sufficient capital and investment to implement non-cash payments as initial guarantees to implement the program. This is the third top priority on implementing non-cash payments at Islamic boarding schools by $11 \%$.

Capital and investment are, of course, the main requirements when the program is launched in an organization; with sufficient capital and investment, the program will be carried out well. Therefore, apart from the service providers, the boarding schools must also invest in implementing this program.

\section{Supervision and support from the central bank}

The fourth top priority is supervision and support from the central bank, Bank Indonesia, which has $10 \%$ of the overall strategy. Bank Indonesia 
supervision and material and non-material support are strategies or solutions for implementing non-cash services at Islamic boarding schools. The task of Bank Indonesia is to develop non-cash instruments/services according to sharia and the characteristics of Islamic boarding schools and support in the form of an e-payment ecosystem to sustain non-cash services.

With reasonable regulations from Bank Indonesia, the implementation of non-cash payments at Islamic boarding schools is considered to be implemented according to the goals and objectives. Therefore, Bank Indonesia argues that Indonesian banks as supervisors, regulators, and mediators to the government, related authorities, amil zakat institutions, and banking industry players will implement non-cash payments at Islamic boarding schools.

\section{The fulfillment of proper facilities and infrastructure}

The fifth top priority in the implementation of non-cash payments is the fulfillment of proper facilities and infrastructure. This will support the implementation of the non-cash payment program in Islamic boarding schools.

\section{Conclusion}

Based on the research results, the main problem was implementing noncash payments at the Al Asy'ariyyah Islamic boarding school, Kalibeber, Wonosobo. Based on a literature review and strengthened by an empirical study and interviews with key persons, three critical aspects of the problem were found. Every aspect is found in its detail in the focus of the problem. The three aspects of the problem include the resource aspect, the communication aspect, and the governance system aspect.

The resource aspect is still concerned with the quality and work ethic of the Islamic boarding school's financial managers, discipline and code of ethics of the financial workers, capital and investment, and insufficient infrastructure. Implementation constraints in the communication aspect 
relate to managers' low trust and attitudes, and the non-cash payment system has not been considered a priority. The interview results also found that parents still like to use cash transactions and are not interested in using noncash payment transactions. Lastly, it is also related to the debate regarding transactions not justified by Islam, such as Riba, Gharar, and Maysir.

In addition to the resource and communication aspects, the system and governance aspects of the Islamic boarding school are also inadequate. No application system is in line with the Islamic boarding school culture. Students are prohibited from using electronic devices. The Islamic boarding school is located in areas where provider signal facilities are insufficient. In addition, bad applications will impact user loyalty and trust in operating non-cash payment systems.

The above constraints are then summarized and studied to find a priority strategy considered to be applied. The strategic cluster that becomes a priority in implementing non-cash payments is the resource aspect of $40 \%$, the communication aspect of $38 \%$, and the last is the governance system aspect of $22 \%$. Therefore, the sub-strategy in this study was taken 5 top priorities to be used as material for the study results, which was considered to overcome problems in implementing non-cash payment transactions in Islamic boarding schools.

The priority sub-strategies are (1) Information and authority for the policy implementation are implemented clearly and guaranteed, (2) Conducting interactive communication regarding the objectives and targets of implementing cashless payments clearly and consistently, (3) Adequacy of capital and investment to ensure the implementation of the program, (4) Supervision and support from the central bank, (5) Fulfillment of adequate facilities and infrastructure.

As a result, stakeholders can consider implementing non-cash payments by prioritizing three main problems, three strategies, and five sub-top priority 
The Implementation Strategy of Non-Cash Payment ...

strategies. That has been submitted based on studies from experts, practitioners, literature studies, and solutions processed by AHP in this study.

\section{References}

Ascarya, Ascarya. 2015. "Determining the Real Causes of Financial Crisis in Islamic Economic Perspective: ANP Approach.” Tazkia Islamic Finance and Business Review 9 (2). https://doi.org/10.30993/TIFBR.V9I2.85.

Baharun, Hasan, and Rizaqil Ardillah. 2019. "Virtual Account Santri : Ikhtiyar Pesantren Dalam Memberikan Layanan Prima Berorientasi Customer Satisfaction Di Pondok Pesantren." ISLAMICONOMIC: Jurnal Ekonomi Islam 10 (1). https://doi.org/10.32678/ijei.v10i1.129.

Bank Indonesia. 2019. Blueprint Sistem Pembayaran Indonesia 2025. Jakarta: Bank Indonesia. https://www.bi.go.id/id/fungsi-utama/sistempembayaran/blueprint-2025/default.aspx.

Dona, Husna Rahma, and Afriva Khaidir. 2018. "Implementasi Pengelolaan Keuangan Dengan Transaksi Non Tunai Di Sekretariat Daerah Provinsi Sumatera Barat." http://jmiap.ppj.unp.ac.id.

Edward III, G. C. 1989. Implementing Public Policy (Implementasi Kebijakan Publik). Terjemahan. Jakarta: PT. Gramedia.

Fatimah, Siti, and Mohammad Syaiful Suib. 2019. "Transformasi Sistem Pembayaran Pesantren Melalui E-Money Di Era Digital (Studi Pondok Pesantren Nurul Jadid)." Jurnal Ekonomi Dan Bisnis 20 (2): 96. https://doi.org/10.30659/ekobis.20.2.96-108.

Firdaus, M, Harmini Harmini, and M.A. Farid. 2011. Aplikasi Metode Kuantitatif Untuk Manajemen Dan Bisnis. Bogor: IPB Press.

Grindle, Merilee S. 2017. "Politics and Policy Implementation in the Third World."

Hendrawan, Suluh, Nur Anisah, and Lina Nasihatun Nafidah. 2019. "Implementasi Transaksi Non-Tunai Sebagai Dasar Tata Kelola Pemerintah Yang Baik: Studi Kasus Pada Pemerintah Kabupaten Jombang." Akuntabilitas $12 \quad$ (2): 227-36. https://doi.org/10.15408/akt.v12i2.12150. 
Ahmad Ghifary Rizalun Nafis, Nurfatin Nazilah Binti Zainol, and Millaturrofi'ah

Kemenag. 2020. "EMIS | Dashboard | Pendis Kemenag." 2020. http://emispendis.kemenag.go.id/dashboard/?content=data-pontren.

Kresnawati, Etik, Ahmad Bunyan Wahib, and Ruspita Rani Pertiwi. 2018. "Pengaruh Metoda Pembayaran Terhadap Perilaku Belanja Dan Donasi Konsumen: Pengujian Teori Mental Accounting Dengan Desain Eksperimental Pada Pra-Penerapan Gerakan Nasional Non-Tunai Di Pondok Pesantren." http://publikasiilmiah.ums.ac.id/handle/11617/10441.

Kusnandar, Viva Budy. 2019a. "Indonesia, Negara Dengan Penduduk Muslim Terbesar Dunia I Databoks." Katadata. 2019. https://databoks.katadata.co.id/datapublish/2019/09/25/indonesianegara-dengan-penduduk-muslim-terbesar-dunia.

_—_. 2019b. "Penduduk Dewasa Indonesia Yang Belum Tersentuh Layanan Finansial Terbanyak Di ASEAN | Databoks." Katadata. 2019. https://databoks.katadata.co.id/datapublish/2019/10/09/pendudukdewasa-indonesia-yang-belum-tersentuh-layanan-finansial-terbanyakdi-asean.

—_- 2019c. "Transaksi Nontunai Di Indonesia Masih Tertinggal Di ASEAN I Databoks." Katadata. 2019. https://databoks.katadata.co.id/datapublish/2019/10/17/transaksinontunai-di-indonesia-masih-tertinggal-di-asean.

Marwini, Marwini, and Annisa Nur Salam. 2020. "E-Money Based Boarding School Cooperative Development Model (Kopontren) As An Sharia Economic Acceleration Effort In Indonesia." AL-ARBAH: Journal of Islamic Finance and Banking 2 (1): 103-17. https://doi.org/10.21580/ALARBAH.2020.2.1.5496.

Nadzir, Mohammad. 2015. "Membangun Pemberdayaan Ekonomi Di Pesantren." Economica: Jurnal Ekonomi Islam 6 (1): 37-56. https://doi.org/10.21580/economica.2015.6.1.785.

Nurul, Maulia, and R. Gratiyana Ningrat. 2019. "Adopsi Teknologi Muslim, Sikap, Dan Intensi Pembelian Produk Investasi Islam Menggunakan Financial Technology." JEBA Uournal of Economics and Business Aseanomics) 3 (2). https://doi.org/10.33476/jeba.v3i2.958.

Parsons, D. W. 1995. "Public Policy: An Introduction to the Theory and Practice of Policy Analysis," 675. 
Ramadhan, Muhammad. 2018. "Implementasi Transaksi Non Tunai Pada Taman Rekreasi Selecta Kota Batu Jawa Timur." Universitas Islam Negeri Maulana Malik Ibrahim. http://etheses.uin-malang.ac.id/13807/.

Ramadhan, Muhammad, and Nihayatu Aslamatis Solekah. 2020. "Implementasi Transaksinon Tunai Pada Taman Rekreasi Selecta Kota Batu Jawa Timur." EKUITAS (Jurnal Ekonomi Dan Keuangan) 4 (1): 6786. https://doi.org/10.24034/j25485024.y2020.v4.i1.111.

Ryandono, Muhamad Nafik Hadi. 2018. "Peran Pondok Pesantren Dalam Pemberdayaan Sosial Ekonomi Di Jawa Timur Pada Abad Ke-20." MOZAIK HUMANIORA 18 (2): 189-204. https://doi.org/10.20473/MOZAIK.V18I2.10934.

Saadah, Munirotus. 2012. "Praktek Ekonomi Islam Di Pondok Pesantren Tahfidzul Qur'an Al-Asy’ariyyah Wonosobo," no. 072411073.

Saaty, Thomas L. 2004. "Decision Making - the Analytic Hierarchy and Network Processes (AHP/ANP)." Journal of Systems Science and Systems Engineering 2004 13:1 13 (1): 1-35. https://doi.org/10.1007/S11518006-0151-5.

_- - 2006. "There Is No Mathematical Validity for Using Fuzzy Number Crunching in the Analytic Hierarchy Process." Journal of Systems Science and Systems Engineering 2006 15:4 15 (4): 457-64. https://doi.org/10.1007/S11518-006-5021-7.

Sutarmin, Sutarmin, and Adi Susanto. 2017. "Potensi Pengembangan Transaksi Non Tunai Di Indonesia." Sustainable Competitive Advantage $\begin{array}{llll}(S C A) & 7 & \text { (1). } & \text { http://jp.feb.unsoed.ac.id/index.php/sca- }\end{array}$ 1/article/view/1025. 
